\title{
Association between CAST and MSTN gene polymorphisms with growth traits in Awassi sheep
}

\author{
Mervan Bayraktar ${ }^{1, *}$, Omer Shoshin ${ }^{2}$ \\ ${ }^{1}$ Dept. of Animal Science, Cukurova University, Adana, Turkey \\ ${ }^{2}$ Dept. of Veterinary collage, Physiology Science, Kirkuk University, Kirkuk, Iraq \\ *Corresponding author: mbayraktar@cu.edu.tr
}

\begin{abstract}
This study aims to identify the association between CAST/MspI and MSTN/HaeIII polymorphism with growth traits in Awassi sheep. A total of 129 (male and female) Awassi sheep were used in the study. Growth traits (Body weight BW, body length BL, chest depth $\mathrm{CD}$, heart girth HG, and withers height $\mathrm{WH}$ ) were taken from animals at one year old. PCRRFLP analysis was used to detect CAST polymorphism (Exon 1C/1D) and MSTN (Exon 3) genes. Three genotypes (MM, MN and NN) were observed for CAST/MspI polymorphism with allele and genotype frequency $0.78(\mathrm{M})$ and $0.22(\mathrm{~N}) ; 0.70(\mathrm{MM}), 0.16(\mathrm{MN})$, and $0.14(\mathrm{NN})$. Two genotypes (MM and $\mathrm{mm}$ ) were found for MSTN/HaeIII polymorphism with allele and genotype frequency as $0.10(\mathrm{M})$ and $0.90(\mathrm{~N}) ; 0.10(\mathrm{MM})$ and $0.90(\mathrm{~mm})$. The genes were in agreement with Hardy-Weinberg equilibrium $(\mathrm{p}>0.05)$. The association analysis showed an association between CAST/MspI polymorphism and BW, BL, CD, and $\mathrm{HG}(\mathrm{P}<0.05)$. The $\mathrm{MM}$ genotypes had the highest BW compared to $\mathrm{MN}$ and $\mathrm{NN}$ genotypes. At the same time, the $\mathrm{MN}$ genotypes had the highest $\mathrm{BL}, \mathrm{CD}$, and $\mathrm{HG}$ compared to $\mathrm{MM}$ and $\mathrm{NN}$ genotypes. No association was found between MSTN/HaeIII polymorphism and growth traits.
\end{abstract}

Keywords: Awassi sheep; CAST; growth traits; MSTN; polymorphism.

\section{Introduction}

Sheep are considered the most suitable agricultural animals for grazing in dry and harsh areas. These areas may not be ideal for other farm animals due to sheep's ability to graze and adapt to environmental conditions. Iraqi sheep belong to the fat-tailed Asian sheep and include Karadi, Arabi, and Awassi. Awassi is a triple-purpose sheep (dairy, meat, and wool) and constitutes about $60 \%$ of native sheep breeds in Iraq (Al Qasimi et al., 2019; Al-Barzinji \& Ameen, 2019). Sheep breeding in Iraq is still taking the traditional methods that depend on grazing in poor areas, so productivity is low. Therefore, it is necessary to follow new management methods nutrition, improve environmental conditions and follow new genetic improvement methods. Increasing the productivity of Awassi requires genetic improvement methods, identifying genetic variation, and determining genes that affect growth and production traits (Al-Salihi et al., 2017; Eghbalsaied et al., 2016; Al-Salameen et al., 2014; Ghani et al., 2021).

Calpastatin (CAST) and myostatin (MSTN) genes directly affect the growth traits in sheep. CAST gene is an endogenous protein that inhibits the effect of calpain (Balcıoglu et al., 2014). Ovine CAST gene is located at chromosome 5 contains 32 exons, 2.701 bp transcript length, and 786 residues of translation length (No: ENSOART00000019281.1). CAST gene plays an essential role in muscle development and meat tenderness after slaughter (Gabor et al., 
2009). MSTN, also known as growth and differentiation factor 8 (GDF8), plays to inhibit muscle growth by preventing muscle fibers formation (Grobet et al., 1997; Kambadur et al., 1997; McPherron \& Lee, 1997). Ovine MSTN gene is located on chromosome 2 (BTA2) and consists of three exons and two introns (Bellinge et al., 2005; Jeanplong et al., 2001; O'Rourke, 2010). The MSTN gene mutations are associated with the double-muscled phenomenon in various mammalian species (Casas et al., 1998; Clop et al., 2006; Mosher et al., 2007; Schuelke et al., 2004). The MSTN gene is related to growth traits in sheep.

The current study aimed to determine the association between CAST and MSTN polymorphisms with growth traits in Awassi sheep.

\section{Material and methods}

\subsection{Experimental animals}

A total of 129 sheep (ram $n=47$, ewe $n=82$ ) of the Awassi breed were used in this study. The animals were raised on a private farm. The farm is located south of Kirkuk city and $50 \mathrm{~km}$ away from the city center. Growth trait data of $\mathrm{BW}, \mathrm{BL}, \mathrm{CD}, \mathrm{HG}$, and $\mathrm{WH}$ were taken from sheep at one year old.

\subsection{Sample collection and DNA extraction}

Genetic analysis was carried out in the molecular genetics laboratory at the College of Veterinary, University of Kirkuk. The blood was collected from the jugular vein using ethylenediamine tetra-acetic acid (EDTA) tubes and stored at $-20^{\circ} \mathrm{C}$. Genomic DNA was extracted from whole blood by using the phenol-chloroform methods. The primer sequence of the CAST and MSTN gene was given in (Table 1). The PCR was done in a reaction volume of $10 \mu \mathrm{L}$, contains $2 \mu \mathrm{L}$ (50ng) DNA, $2.5 \mu \mathrm{L}$ of PCR Master Mix (GoTaq® G2 Green Master Mix, Promega, USA), $0.25 \mu \mathrm{L}$ for each primer $(10 \mu \mathrm{mol})$ and $5 \mu \mathrm{L}$ distilled water. PCR conditions for the CAST and MSTN genes are given in (Table 2).

\subsection{PCR-RFLP method}

CAST locus was digested with MspI enzyme and MSTN digested by HaeIII enzyme (Promega, USA). The mix consisted of $5 \mu \mathrm{L}$ PCR product, $3.5 \mu \mathrm{L}$ distilled water, $1 \mu \mathrm{L} 10 \mathrm{X}$ buffer, and $0.5 \mu \mathrm{L}$ restriction enzyme (Total of $10 \mu \mathrm{L}$ ). Digestion products were separated on $2 \%$ agarose gel at $95 \mathrm{~V}$ for $60 \mathrm{~min}$. The gel was stained with ethidium bromide and used a 100bp DNA marker (Promega, USA). The results were checked under ultraviolet light.

Table 1. The primer sequences of CAST and MSTN gene

\begin{tabular}{c|l|c|c}
\hline Gene & \multicolumn{1}{|c|}{ primer sequences } & position & Source \\
\hline \multirow{2}{*}{ CAST } & $\begin{array}{l}\text { F/5'TGGGGCCCAATGACGCCATCGATG-3' } \\
\text { R/5'GGTGGAGCAGCACTTCTGATCACC-3' }\end{array}$ & Exon 1C/1D & $\begin{array}{c}\text { Palmer et al. } \\
(1998)\end{array}$ \\
\hline \multirow{2}{*}{ MSTN } & $\begin{array}{l}\text { F/5'CCGGAGAGACTTTGGGCTTGA-3' } \\
\text { F/5'TCATGAGCACCCACAGCGGTC-3' }\end{array}$ & Exon 3 & $\begin{array}{c}\text { Smith et al. } \\
(1997)\end{array}$ \\
\hline
\end{tabular}

\subsection{Statistical Analysis}

The allele and genotype frequency of the genes and the Chi-square test $\chi^{2}$ were calculated by popgen 32 (ver.1.32). Growth traits were analyzed using the General Linear Model (GLM) of 
Minitab 16. The least-squares means were compared using Tukey, the least significant difference test.

The general linear model was:

Yijk $=\mu+\alpha i+\beta j+\alpha \beta i j+e i j k$

Yijk: traits measured; $\mu$ : overall mean for each trait; $\alpha \mathrm{i}$ : sex effect; $\beta \mathrm{j}$ : genotypes effect; $\alpha \beta \mathrm{ij}$ : interaction between genotype and sex; eijk: random error

\section{Results}

\subsection{CAST/MspI polymorphism}

622 bp of PCR product was amplified. Three genotypes (MM, MN, and NN) were obtained (Figure 1). MM genotype was 336 bp and 286 bp; MN genotype was 622 bp, 336 bp, and 286 bp; NN genotype was $622 \mathrm{bp}$. Chi-square $\chi^{2}$ test showed agreement to Hardy-Weinberg equilibrium ( $p>0.05$ ) (Tablo 3). The allele and genotype frequency was $0.78(\mathrm{M})$ and $0.22(\mathrm{~N})$; $0.70(\mathrm{MM}), 0.16(\mathrm{MN})$, and $0.14(\mathrm{NN})$. M Allele showed a high frequency from the $\mathrm{N}$ allele.

\subsection{MSTN/HaeIII polymorphism}

$337 \mathrm{bp}$ of PCR product was amplified. Two genotypes (MM, and $\mathrm{mm}$ ) were observed. MM genotype was $337 \mathrm{bp}$, whereas mm genotype was 131 and 123 (Figure 2) bp. $\chi^{2}$ test showed agreement to Hardy-Weinberg equilibrium ( $>0.05$ ) (Table 3$)$. The allele and genotype frequency was $0.10(\mathrm{M})$ and $0.90(\mathrm{~m}) ; 0.10(\mathrm{MM})$ and $0.90(\mathrm{~mm})$ respectively.

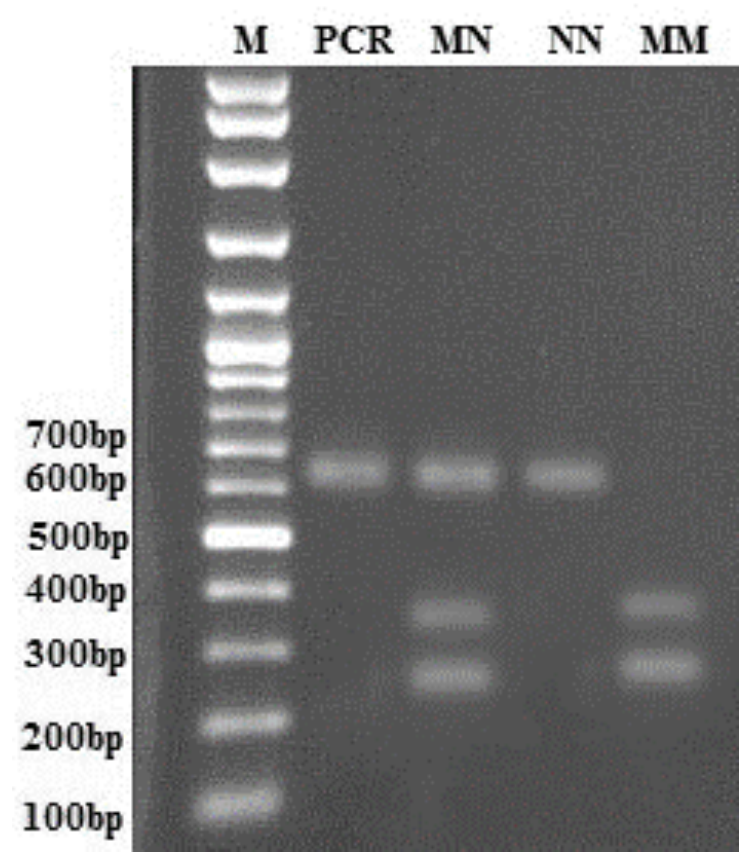

Fig. 1. PCR-RFLP analysis of the CAST/MspI polymorphism. 622 bp PCR fragment; 622 bp, $336 \mathrm{bp}$, and $286 \mathrm{bp}$ for MN genotype; $622 \mathrm{bp}$ for NN genotype; $336 \mathrm{bp}$ and $286 \mathrm{bp}$ for MM genotype 


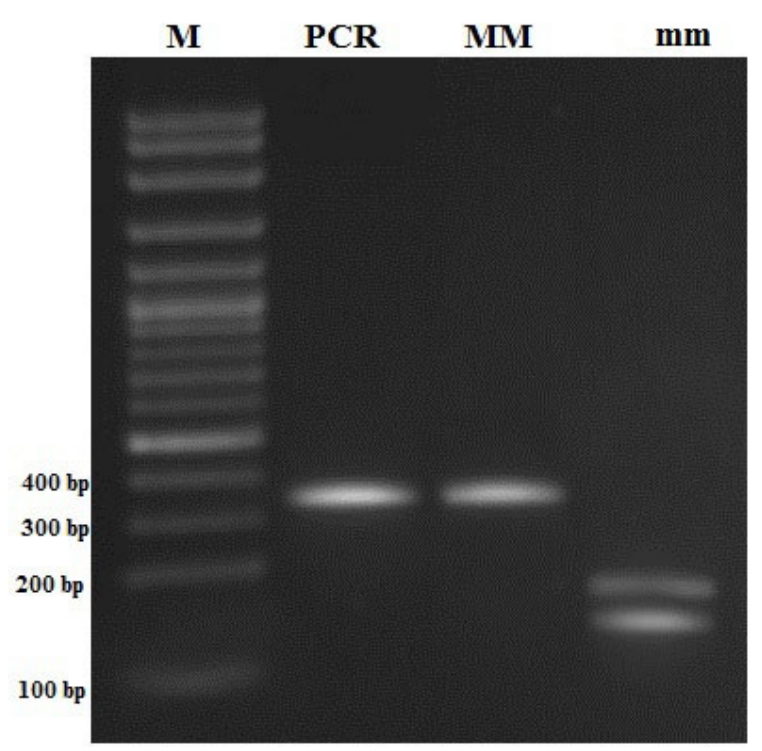

Fig. 2. PCR-RFLP analysis of the MSTN/HaeIII polymorphism. $337 \mathrm{bp}$ PCR fragment; 337 bp for MM genotype; $131 \mathrm{bp}$ and $123 \mathrm{bp}$ for mm genotype

Table 2. Allele and genotype frequencies of CAST/MspI and MSTN/HaeIII polymorphisms

\begin{tabular}{|c|c|c|c|c|c|c|}
\hline \multirow[t]{2}{*}{ Gene } & \multicolumn{2}{|c|}{ Allele Frequency } & \multicolumn{3}{|c|}{ Genotype Frequency } & \multirow{3}{*}{$\begin{array}{c}\chi^{2} \\
39.76\end{array}$} \\
\hline & $M$ & $\mathrm{~N}$ & MM & $\mathrm{MN}$ & $\mathrm{NN}$ & \\
\hline CAST & 0.78 & 0.22 & 0.70 & 0.16 & 0.14 & \\
\hline & $\mathrm{M}$ & $\mathrm{m}$ & MM & $\mathrm{Mm}$ & $\mathrm{mm}$ & \\
\hline MSTN & 0.10 & 0.90 & 0.10 & 0.00 & 0.90 & 129 \\
\hline
\end{tabular}

\subsection{Association analysis}

3.3.1 Association between polymorphisms and growth traits

Association analysis showed a significant effect of CAST locus on the growth traits $(\mathrm{P}<0.05)$. The animals with MM genotypes had the highest BW from MN and NN genotypes (Table 3). The MN genotypes had the highest $\mathrm{BL}, \mathrm{CD}, \mathrm{HG}$, and $\mathrm{WH}$ than $\mathrm{MM}$ and $\mathrm{NN}$ genotypes. A significant interaction was observed between body length, chest depth, and Heart girth with sex. MSTN locus had no significant effect on growth traits ( $\mathrm{P}>0.05)$ (Table 4).

Table 3. Association analysis between CAST genotypes and growth traits

\begin{tabular}{lccccc}
\hline \multirow{2}{*}{ Traits } & \multicolumn{2}{c}{ Genotypes (mean \pm standard error) } & \multirow{2}{*}{ p-value } & \multirow{2}{*}{$\mathrm{G}^{*} \mathrm{~S}$} \\
\cline { 2 - 4 } & $43.22 \pm 0,097^{\mathrm{a}}$ & $42,68 \pm 0,131^{\mathrm{b}}$ & $42.86 \pm 0.135^{\mathrm{ab}}$ & $0.003^{*}$ & 0.383 \\
\hline Body weight, $\mathrm{kg}$ & $55.10 \pm 0.119^{\mathrm{b}}$ & $55.67 \pm 0.159^{\mathrm{a}}$ & $55.01 \pm 0.165^{\mathrm{b}}$ & $0.006^{*}$ & 0.016 \\
Body length, cm & $30.00 \pm 0.105^{\mathrm{ab}}$ & $30.38 \pm 0.140^{\mathrm{a}}$ & $29.87 \pm 0.145^{\mathrm{b}}$ & $0.028^{*}$ & 0.064 \\
Chest depth, cm & $87.96 \pm 0.095^{\mathrm{ab}}$ & $88.29 \pm 0.128^{\mathrm{a}}$ & $87.84 \pm 0.132^{\mathrm{b}}$ & $0.033^{*}$ & 0.002 \\
Heart girth, cm & $67.51 \pm 0.098$ & $67.87 \pm 0.132$ & $67.80 \pm 0.138$ & 0.063 & 0.764 \\
Wither height, cm & & &
\end{tabular}

$\mathrm{G}^{*} \mathrm{~S}$ : interaction between genotype and sex; ${ }^{*} \mathrm{P}<0.05$ 
Table 4. Association analysis between MSTN genotypes and growth traits

\begin{tabular}{|c|c|c|c|c|}
\hline \multirow{2}{*}{ Traits } & \multicolumn{2}{|c|}{ Genotypes (mean \pm standard error) } & \multirow{2}{*}{ p-value } & \multirow{2}{*}{$\mathrm{G}^{*} \mathrm{~S}$} \\
\hline & $\mathrm{MM}$ & $\mathrm{mm}$ & & \\
\hline Body weight. kg & $42.92 \pm 0.090$ & $42.92 \pm 0.108$ & 0.970 & 0.562 \\
\hline Body length. cm & $55.22 \pm 0.110$ & $55.30 \pm 0.132$ & 0.650 & 0.389 \\
\hline Chest depth. cm & $30.15 \pm 0.097$ & $30.01 \pm 0.116$ & 0.353 & 0.228 \\
\hline Heart girth. cm & $88.02 \pm 0.088$ & $88.04 \pm 0.106$ & 0.866 & 0.642 \\
\hline Wither height. $\mathrm{cm}$ & $67.73 \pm 0.092$ & $67.72 \pm 0.111$ & 0.947 & 0.343 \\
\hline
\end{tabular}

$\mathrm{G}^{*} \mathrm{~S}$ : interaction between genotype and sex

\section{Discussion}

CAST gene directly affects growth traits and meat characteristics. In this study, we identified three genotypes (MM. MN and NN) of CAST/MspI polymorphism, with allele and genotype frequency $0.78(\mathrm{M})$ and $0.22(\mathrm{~N}) ; 0.70(\mathrm{MM}), 0.16(\mathrm{MN})$, and $0.14(\mathrm{NN})$. Previous studies reported that the $\mathrm{M}$ allele is more frequent than the $\mathrm{N}$ allele in most sheep breeds (Table 5). We also found a high frequency for the $\mathrm{M}$ allele. Nassiry et al. (2006) determined the A allele frequency in the Kurdi sheep as 0.78. Khederzadeh et al. (2016) showed the A allele frequency as 0.78 in Zandi sheep. Also, Jawasreh et al. (2019a) noted M allele frequency in Awassi sheep as 0.77. Eftekhari et al. (2006) observed M allele frequency in Karakul sheep as 0.79. The association analysis showed a significant association between CAST polymorphism and growth traits. The MM genotypes had the highest BW compared to $\mathrm{MN}$ and $\mathrm{NN}$ genotypes. In contrast, the MN genotypes had the highest BL, CD, and $\mathrm{HG}$ from MM and NN genotypes. Nassiry et al. (2006) observed the association between CAST polymorphism and average daily gain from birth to weaning in Kurdi sheep. Byun et al. (2008) reported the CAST genes effect on birth weight in New Zealand Romney sheep. Sutikno et al. (2011) found no association between CAST polymorphism and bodyweight of Indonesian native sheep. Chung \& Davis (2012) found an association between CAST polymorphism and growth traits in Playpay, Targhee, and crossbreed sheep. Nikmard et al. (2012) did not find an association between CAST polymorphism and growth traits in Afshari sheep. Khan et al. (2012) showed an association between CAST polymorphism and average daily gain in Balkhi and Kajli sheep. Yilmaz et al. (2014) determined the effect of CAST on the average daily gain in Kivircik lambs. Ibrahim et al. (2015) did not observe the effect of CAST on the growth traits in Barki sheep. Gorlov et al. (2016) detected an association between CAST polymorphism and growth traits in Salsk sheep. Ihsan et al. (2016) revealed an association between CAST polymorphism and average daily gain in Indonesian thin tail sheep. Jawasreh et al. (2017) confirmed a significant association between CAST polymorphism and final body weight and average daily gain in Awassi sheep. Bayram et al. (2019) did not find a CAST effect on body weight in Akkaraman lambs. Afanasyeva et al. (2019) determined the association between CAST polymorphism and average daily weight gain in the West Siberian mutton breed. Jawasreh \& Ismail (2019b) demonstrated the CAST effect on final body weight in Awassi sheep. Machado et al. (2020) identified the association of CAST with growth traits in Ines sheep. Al-Barzinji \& Ameen (2019) showed that lambs with $\mathrm{AB}$ genotype had a higher body weight at all ages and higher average daily gain. 
MSTN gene inhibits muscle cell growth. When loss of the vital function of the MSTN gene causes the double-muscled in the sheep (Broad et al., 2000).

We detected two genotypes (MM and $\mathrm{mm}$ ) of MSTN locus, with allele and genotype frequency $0.10(\mathrm{M})$ and $0.90(\mathrm{~N}) ; 0.10(\mathrm{MM})$ and $0.90(\mathrm{~mm})$. Soufy et al. (2009) observed three genotypes in Sanjabi Sheep with genotype frequency 0.02(MM), 0.01(Mm), and $0.97(\mathrm{~mm})$. Sahu et al. (2017) reported two genotypes (MM and Mm) in Madras Red and Mecheri sheep breeds at G5622C locus in exon 3 of MSTN/MspI polymorphism with genotype frequency as $0.41(\mathrm{MM})$ and $0.58(\mathrm{Mm}) ; 0.48(\mathrm{MM})$ and $0.51(\mathrm{Mm})$ respectively. In contrast, two genotypes (Mm and $\mathrm{mm}$ ) were shown in Kordi, Kalehkoohi, Farahani, Mehraban, and Teleorman sheep breeds (Akbari et al., 2015; Ebrahimi et al., 2014; Jamshidi et al., 2014; Lazar et al., 2016; Shariatzadeh et al., 2014). Most studies confirm that the MSTN/HaeIII at exon 3 is monomorphic in the different sheep breeds (Table 6). The reason may be the small sample size, environmental effect, geographical position, and mating strategies. Association analysis showed no significant association between MSTN/HaeIII polymorphism and growth traits $(\mathrm{P}>0.05)$. There are not many association studies because of the monomorphic at the MSTN/HaeIII gene locus. Sahu et al. (2017) found an association between genotypes at G5622C locus in exon 3 of MSTN/MspI site and body weight at 9 and 12 months.

Table 5. Distribution of Allele Frequency in the CAST gene at some sheep breeds

\begin{tabular}{|c|c|c|c|c|}
\hline References & Breed & $\mathbf{N}$ & \multicolumn{2}{|c|}{ Allele frequency } \\
\hline \multirow{2}{*}{ Nassiry et al. (2006) } & \multirow{2}{*}{ Kurdi sheep } & \multirow{2}{*}{84} & \multirow{2}{*}{$0.78(\mathrm{~A})$} & $0.16(\mathrm{~B})$ \\
\hline & & & & $0.06(\mathrm{C})$ \\
\hline Eftekhari et al. (2006) & Karakul sheep & 100 & $0.79(\mathrm{M})$ & $0.21(\mathrm{~N})$ \\
\hline Mohammadi et al. (2008) & Arabic sheep & 111 & $0.85(\mathrm{~A})$ & $0.15(\mathrm{~B})$ \\
\hline \multirow{2}{*}{ Gabor et al. (2009) } & Tsigai sheep & 58 & $0.91(\mathrm{M})$ & $0.09(\mathrm{~N})$ \\
\hline & Improved valachian & 19 & $0.97(\mathrm{M})$ & $0.03(\mathrm{~N})$ \\
\hline \multirow{2}{*}{$\begin{array}{l}\text { Szkudlarek-Kowalczyk et al. } \\
\text { (2011) }\end{array}$} & Polish Merino & 82 & $0.76(\mathrm{M})$ & $0.24(\mathrm{~N})$ \\
\hline & Berrichon du Cher & 41 & $0.93(\mathrm{M})$ & $0.7(\mathrm{~N})$ \\
\hline Sutikno et al. (2011) & Local Sheep & 264 & $0.86(\mathrm{M})$ & $0.14(\mathrm{~N})$ \\
\hline Nanekarani et al. (2011) & Atabi sheep & 120 & $0.81(\mathrm{~A})$ & 0.19 (B) \\
\hline Dehnavi et al. (2012a) & Zel sheep & 200 & $0.85(\mathrm{M})$ & $0.15(\mathrm{~N})$ \\
\hline \multirow{2}{*}{ Chung \& Davis (2012) } & Polypay & 116 & $0.53(\mathrm{~A})$ & $0.47(\mathrm{~B})$ \\
\hline & Targhee & 110 & $0.18(\mathrm{~A})$ & $0.82(\mathrm{~B})$ \\
\hline Gharahveysi et al. (2012) & Zel sheep & 100 & $0.75(\mathrm{M})$ & $0.25(\mathrm{~N})$ \\
\hline \multirow{2}{*}{ Khan et al. (2012) } & Balkhi & 300 & $0.88(\mathrm{M})$ & $0.12(\mathrm{~N})$ \\
\hline & Kajli & 300 & $0.86(\mathrm{M})$ & $0.14(\mathrm{~N})$ \\
\hline Azari et al. (2012) & Dalagh sheep & 110 & $0.55(\mathrm{~A})$ & $0.45(\mathrm{~B})$ \\
\hline \multirow{2}{*}{ Ranjbari et al. (2012) } & \multirow{2}{*}{ Makoei Sheep } & \multirow{2}{*}{100} & \multirow{2}{*}{$0.63(\mathrm{~A})$} & $0.36(\mathrm{~B})$ \\
\hline & & & & $0.01(\mathrm{C})$ \\
\hline \multirow{2}{*}{ Suleman et al. (2012) } & Thalli & 100 & $0.90(\mathrm{M})$ & $0.10(\mathrm{~N})$ \\
\hline & Lohi & 100 & $0.87(\mathrm{M})$ & $0.13(\mathrm{~N})$ \\
\hline \multirow{2}{*}{ Ata (2012) } & Çine çaparı & 97 & $0.74(\mathrm{M})$ & $0.26(\mathrm{~N})$ \\
\hline & Karya sheep & 90 & $0.54(\mathrm{M})$ & $0.46(\mathrm{~N})$ \\
\hline Nikmard et al. (2012) & Afshari sheep & 51 & $0.74(\mathrm{M})$ & $0.26(\mathrm{~N})$ \\
\hline \multirow{2}{*}{ Balcığlu et al. (2014) } & Kangal & 31 & $0.92(\mathrm{M})$ & $0.08(\mathrm{~N})$ \\
\hline & Awassi & 26 & $0.59(\mathrm{M})$ & $0.41(\mathrm{~N})$ \\
\hline
\end{tabular}




\begin{tabular}{|c|c|c|c|c|}
\hline Nanekarani \& Goodarzi (2014) & Lori sheep & 120 & $0.63(\mathrm{~A})$ & $0.37(\mathrm{~B})$ \\
\hline \multirow{2}{*}{ Avanus (2015) } & Kivircik & 25 & $0.70(\mathrm{M})$ & $0.30(\mathrm{~N})$ \\
\hline & Karakul & 15 & $0.73(\mathrm{M})$ & $0.27(\mathrm{~N})$ \\
\hline \multirow{3}{*}{ Ibrahim et al. (2015) } & & & & $0.13(\mathrm{~N})$ \\
\hline & Barki sheep & 42 & $0.62(\mathrm{M})$ & $0.10(\mathrm{O})$ \\
\hline & & & & $0.15(\mathrm{P})$ \\
\hline Georgieva et al. (2015) & Shumen & 121 & $0.92(\mathrm{M})$ & $0.08(\mathrm{~N})$ \\
\hline \multirow{2}{*}{ Mahrous et al. (2015) } & Barki & 20 & $0.68(\mathrm{M})$ & $0.32(\mathrm{~N})$ \\
\hline & Rahmani & 20 & $0.80(\mathrm{M})$ & $0.20(\mathrm{~N})$ \\
\hline \multirow{2}{*}{ Gorlov et al. (2016) } & Soviet merino & 72 & $0.88(\mathrm{M})$ & $0.12(\mathrm{~N})$ \\
\hline & Salsk & 108 & $0.89(\mathrm{M})$ & $0.11(\mathrm{~N})$ \\
\hline $\begin{array}{l}\text { Bozhilova-Sakova \& Dimitrova } \\
(2016)\end{array}$ & Karakachan sheep & 25 & $1.00(\mathrm{M})$ & - \\
\hline Khederzadeh et al. (2016) & Zandi sheep & 100 & $0.78(\mathrm{~A})$ & $0.22(\mathrm{~B})$ \\
\hline Jawasreh et al. (2017) & Awassi & 80 & $0.49(\mathrm{M})$ & $0.51(\mathrm{~N})$ \\
\hline Kaplan \& Atalay (2017) & Kivircık & 100 & $0.90(\mathrm{M})$ & $0.10(\mathrm{~N})$ \\
\hline Ibrahim \& Kali (2017) & Awassi & 40 & $0.86(\mathrm{M})$ & $0.14(\mathrm{~N})$ \\
\hline \multirow{2}{*}{ Kulikova et al. (2018) } & Tuvan steppe type & 51 & $0.89(\mathrm{M})$ & $0.11(\mathrm{~N})$ \\
\hline & Tuvan mountain type & 100 & $0.88(\mathrm{M})$ & $0.12(\mathrm{~N})$ \\
\hline Bayram et al. (2019) & Akkaraman & 374 & $0.90(\mathrm{M})$ & $0.10(\mathrm{~N})$ \\
\hline \multirow{2}{*}{ Gaitonde (2018) } & Deccani & 50 & $0.75(\mathrm{M})$ & $0.25(\mathrm{~N})$ \\
\hline & Madgyal & 50 & $0.62(\mathrm{M})$ & $0.38(\mathrm{~N})$ \\
\hline Pomitun et al. (2019) & Kharkiv & 47 & $0.83(\mathrm{M})$ & $0.17(\mathrm{~N})$ \\
\hline Afanasyeva et al. (2019) & West Siberian mutton breed & 100 & $0.84(\mathrm{M})$ & $0.16(\mathrm{~N})$ \\
\hline \multirow{2}{*}{ Montes et al. (2019) } & Valle del Cauca & 150 & $0.91(\mathrm{M})$ & $0.09(\mathrm{~N})$ \\
\hline & Sucre & 150 & $0.92(\mathrm{M})$ & $0.08(\mathrm{~N})$ \\
\hline Jawasreh et al. (2019a) & Awassi & 87 & $0.77(\mathrm{M})$ & $0.23(\mathrm{~N})$ \\
\hline Jawasreh \& Ismail (2019b) & Awassi & 31 & $0.49(\mathrm{M})$ & $0.51(\mathrm{~N})$ \\
\hline Al-Barzinji \& Ameen (2019) & Awassi & 52 & $0.12(\mathrm{~A})$ & $0.88(\mathrm{~B})$ \\
\hline
\end{tabular}

Table 6. Distribution of Allele Frequency in the MSTN gene at some sheep breeds

\begin{tabular}{lllll}
\hline \multicolumn{1}{c}{ References } & \multicolumn{1}{c}{ Breed } & N & \multicolumn{2}{c}{ Allele frequency } \\
\hline Soufy et al. $(2009)$ & Sanjabi & 150 & $0.03(\mathrm{M})$ & $0.97(\mathrm{~m})$ \\
\hline Dehnavi et al. $(2012 \mathrm{~b})$ & Zel & 200 & - & $1.00(\mathrm{~m})$ \\
\hline Azari et al. (2012) & Dalagh & 110 & - & $1.00(\mathrm{~m})$ \\
\hline Zare \& Mirhosseini (2013) & Karakul & 100 & - & $1.00(\mathrm{~m})$ \\
& & & & \\
\hline Elkorshy et al. (2013) & Barki & 25 & - & $1.00(\mathrm{~m})$ \\
\cline { 2 - 5 } & Rahmani & 24 & - & $1.00(\mathrm{~m})$ \\
\cline { 2 - 5 } & Saidi & 25 & - & $1.00(\mathrm{~m})$ \\
\cline { 2 - 5 } & Najdi & 21 & - & $1.00(\mathrm{~m})$ \\
\cline { 2 - 5 } & Harri & 22 & - & $1.00(\mathrm{~m})$ \\
\cline { 2 - 5 } & Ossimi & 23 & - & $1.00(\mathrm{~m})$ \\
\hline Nada et al. (2013) & Barki & 25 & - & $1.00(\mathrm{~m})$ \\
\cline { 2 - 5 } & Ossimi & 48 & - & $1.00(\mathrm{~m})$ \\
\hline
\end{tabular}




\begin{tabular}{|c|c|c|c|c|}
\hline Ebrahimi et al. (2014) & Kalehkoohi & 96 & $0.20(\mathrm{M})$ & $0.80(\mathrm{~m})$ \\
\hline Shariatzadeh et al. (2014) & Farahani Sheep & 86 & $0.11(\mathrm{M})$ & $0.89(\mathrm{~m})$ \\
\hline Jamshidi et al. (2014) & Mehraban & 120 & $0.03(\mathrm{M})$ & $0.97(\mathrm{~m})$ \\
\hline Georgieva et al. (2015) & Shumen & 121 & - & $1.00(\mathrm{~m})$ \\
\hline Akbari et al. (2015) & Kordi sheep & 58 & $0.08(\mathrm{M})$ & $0.92(\mathrm{~m})$ \\
\hline Bozhilova-Sakova et al. (2016) & Karakachan & 25 & - & $1.00(\mathrm{~m})$ \\
\hline Dimitrova et al. (2016) & Bulgarian Merino & 32 & - & $1.00(\mathrm{~m})$ \\
\hline Othman et al. (2016) & Egyptian sheep & 171 & - & $1.00(\mathrm{~m})$ \\
\hline Khederzadeh et al. (2016) & Zandi sheep & 100 & - & $1.00(\mathrm{~m})$ \\
\hline Lazar et al. (2016) & Teleorman & 105 & $0.42(\mathrm{M})$ & $0.58(\mathrm{~m})$ \\
\hline \multirow[t]{2}{*}{ Sahu et al. (2017) } & Madras Red & 127 & $0.71(\mathrm{M})$ & $0.29(\mathrm{~m})$ \\
\hline & Mecheri & 105 & $0.74(\mathrm{M})$ & $0.26(\mathrm{~m})$ \\
\hline Bozhilova-Sakova \& Dimitrova (2017) & France & 30 & - & $1.00(\mathrm{~m})$ \\
\hline Khederzadeh et al. (2017) & Shirazi Sheep & 102 & - & $1.00(\mathrm{~m})$ \\
\hline Dimitrova et al. (2017) & Karnobat Merino & 35 & - & $1.00(\mathrm{~m})$ \\
\hline \multirow[t]{2}{*}{ Dimitrova et al. (2019) } & Ascanian merino & 31 & - & $1.00(\mathrm{~m})$ \\
\hline & Caucasian merino & 30 & - & $1.00(\mathrm{~m})$ \\
\hline Al-Barzinji \& Ameen (2019) & Awassi & 52 & - & $1.00(\mathrm{~B})$ \\
\hline
\end{tabular}

\section{Conclusion}

This study found a significant association between the CAST/MspI and MSTN/HaeIII polymorphisms and growth traits in Awassi sheep. As the genes showed polymorphisms in Awassi sheep, these genes can be considered important genetic markers. They can be used as markers in genetic improvement programs to improve sheep breeds' growth traits.

\section{References}

Afanasyeva, A., Sarychev, V. \& Goncharenko, G. (2019) Phenotypic effects of polymorphism of the calpastatin gene (CAST), associated with growth and development indicators, in the West Siberian mutton breed. International scientific and practical conference. Paris, France.

Akbari, S., Dashab, G., Alipanah, M., Rokouei, M. \& Saghi, D. (2015) Study on the polymorphism in myostatin gene and its association with growth traits in Kordi sheep of Northern Khorasan Modern Genetics Journal, 10(1):129-133. 
Al-Barzinji, Y. \& Ameen, A. (2019) Specific genes affecting body weight in Iraqi awassi sheep. Journal of Duhok University, 22(2):187-195.

Al-Salameen, F., Al-Amad, S. \& Al-Hashash, H. (2014) Determination of genetic variation of Rhanterium epapposum in Kuwait desert using RAPD and SRAP DNA-based markers. Kuwait Journal of Science, 41(3):163-175.

Al-Salihi, A., Al-Saadi, B. \& Al-Anbari, N. (2017) Genotypes Relationship of Growth Hormone Gene Polymorphism with Some Productive and Reproductive Trait in Awassi Sheep. Journal of Biotechnology Research Center, 11(2):26-33.

Al Qasimi, R. H., Hassan, A. F. \& Khudair, B. Y. (2019) Effect of IGF-1 and GH Genes polymorphism on weights and body measurements of Awassi lambs in different ages. Basrah Journal of Agricultural Sciences, 32(1):39-46.

Ata, N. (2012) Detecting calpastatin gene polymorphism with PCR-rflp method in çine çapari and karya sheep. Ph.D. thesis, Adnan Menderes University, Aydın, Turkey.

Avanus, K. (2015) Genetic variability of CAST gene in native sheep breeds of Turkey. Kafkas Universitesi Veteriner Fakultesi Dergisi, 21(6):789-794.

Azari, M. A., Dehnavi, E., Yousefi, S. \& Shahmohamadi, L. (2012) Polymorphism of calpastatin, calpain and myostatin genes in native Dalagh sheep in Iran. Slovak Journal of Animal Science, 45(1):1-6.

Balcıoğlu, M., Karslı, T., Şahin, E., Ulutașc, Z. \& Aksoy, Y. (2014) Determination of calpastatin (CAST) gene polimorphism in some native sheep breeds reared in Turkey by PCRRFLP method. Tarim Bilimleri Dergisi, 20(4):427-433.

Bayram, D., Akyüz, B., Arslan, K., Özdemİr, F., Aksel, E. G. \& Çinar, M. U. (2019) DGAT1, CAST and IGF-I gene polymorphisms in Akkaraman lambs and their effects on live weights up to weaning age. Kafkas Universitesi Veteriner Fakultesi Dergisi, 25(1):9-15.

Bellinge, R., Liberles, D. A., Iaschi, S., O'brien, P. \& Tay, G. (2005) Myostatin and its implications on animal breeding: a review. Animal genetics, 36(1):1-6.

Bozhilova-Sakova, M. \& Dimitrova, I. (2016) PCR-RFLP Analysis of CAST gene in one Bulgarian sheep breed. ATINER'S Conference Paper Series. Athens, Greece.

Bozhilova-Sakova, M. \& Dimitrova, I. (2017) PCR-RFLP analysis of three genes associated with meat productivity in Il de France sheep breed. Proceedings of Scientific Conference with International Participation, Sofia, Bulgaria. 
Bozhilova-Sakova, M., Dimitrova, I., Teneva, A. \& Petrov, N. (2016) PCR-RFLP analysis of MSTN gene in karakachan sheep breed. Bulgarian Journal of Agricultural Science, 22(1):115-117.

Broad, T., Glass, B., Greer, G., Robertson, T., Bain, W., Lord, E., McEwan, J. \& Peterson, S. (2000) Search for a locus near to myostatin that increases muscling in Texel sheep in New Zealand. Proceedings-new Zealand society of animal production. New Zealand.

Byun, S., Zhou, H., Forrest, R., Frampton, C. \& Hickford, J. (2008) Association of the ovine calpastatin gene with birth weight and growth rate to weaning. Animal genetics, 39(5):572-576.

Casas, E., Keele, J., Shackelford, S., Koohmaraie, M., Sonstegard, T., Smith, T., Kappes, S. \& Stone, R. (1998) Association of the muscle hypertrophy locus with carcass traits in beef cattle. Journal of Animal Science, 76(2):468-473.

Chung, H. \& Davis, M. (2012) PCR-RFLP of the ovine calpastatin gene and its association with growth. Asian Journal of Animal and Veterinary Advances, 7(8):641-652.

Clop, A., Marcq, F., Takeda, H., Pirottin, D., Tordoir, X., Bibé, B., Bouix, J., Caiment, F., Elsen, J.-M. \& Eychenne, F. (2006) A mutation creating a potential illegitimate microRNA target site in the myostatin gene affects muscularity in sheep. Nature genetics, 38(7):813-818.

Dehnavi, E., AHANI, A. M., Hasani, S., Nassiry, M. R., Mohajer, M. \& KHAN, A. A. R. (2012a) Genetic variability of calpastatin and calpain genes in Iranian Zel sheep using PCRRFLP and PCR-SSCP methods. Iranian Journal of Biotechnology, 10(2):136-139.

Dehnavi, E., Azari, M. A., Hasani, S., Nassiry, M. R., Mohajer, M., Khan Ahmadi, A., Shahmohamadi, L. \& Yousefi, S. (2012b) Polymorphism of myostatin gene in intron 1 and 2 and exon 3, and their associations with yearling weight, using PCR-RFLP and PCR-SSCP techniques in Zel sheep. Biotechnology Research International, 2012(3):1-5.

Dimitrova, I., Bozhilova-Sakova, M., Ignatova, M., Genova, K., Ivanova, T., Teneva, A., Stoikovagrigorova, R. \& Koutev, V. (2019) Study of the mstn gene in sheep of caucasian merino and ascanian merino breeds in bulgaria. International Congress on domestic animal breeding. Prague, Czechia.

Dimitrova, I., Bozhilova-Sakova, M. \& Iliev, M. (2017) Study of some genes associated with meat productivity in Karnobat Merino sheep breed using PCR-RFLP. Journal of Agriculture and Veterinary Science, 10(8):61-65.

Dimitrova, I., Bozhilova-Sakova, M., Stancheva, N. \& Tzonev, T. (2016) Molecular Analysis Of Ovine Myostatin Gene (MSTN) In Northeast Bulgarian Merino Sheep Breed Using PCR-RFLP. Bulgarian Journal of Agricultural Science, 22(2):1-3. 
Ebrahimi, A., Rafiei, F. \& Nanakrani, S. (2014) Genetic polymorphism of mstn gene in kalehkoohi sheep by PCR-rflp method. The $1^{\text {st }}$ international conference on new ideas in agriculture. Isfahan, Iran.

Eftekhari, S. F., Nassiry, M. R., Valizadh, R., Heravi Moussavi, A., Tahmoores Pour, M. \& Ghiasi, H. (2006) Genetic polymorphism at MTNR1A, CAST and CAPN loci in Iranian Karakul sheep. Iranian Journal of Biotechnology, 4(2):117-122.

Eghbalsaied, S., Akasheh, L., Honarvar, M., Forouzandeh, A. D., Ghazikhani-Shad, A., Bankizadeh, F. \& Abdullahpour, R. (2016) Fine-tuning of season definition for genetic analysis of fertility, productivity, and longevity traits in Iranian Holstein dairy cows. Kuwait Journal of Science, 43(1):69-83.

Elkorshy, N., Mahrous, K. F. \& Salem, L. M. (2013) Genetic Polymorphism Detection in Four Genes in Egyptian and Saudi Sheep Breeds. World Applied Sciences Journal, 27(1):3343.

Gabor, M., Trakovická, A. \& Miluchová, M. (2009) Analysis of polymorphism of CAST gene and CLPG gene in sheep by PCR-RFLP method. Scientific Papers Animal Science and Biotechnologies, 42(2):470-476.

Gaitonde, A. (2018) Genotyping of MSTN and Cast Gene in Deccani and Madgyal Sheep Using PCR-RFLP. M.V.Sc. thesis, Maharashtra Animal and Fishery Sciences University, Nagpur, India.

Georgieva, S., Hristova, D., Dimitrova, I., Stancheva, N. \& Bozhilova-Sakova, M. (2015) Molecular analysis of ovine calpastatin (CAST) and myostatin (MSTN) genes in Synthetic Population Bulgarian Milk sheep using PCR-RFLP. Journal of BioScience \& Biotechnology, 4(1):95-99.

Ghani, M. U., Sabar, M. F. \& Akram, M. (2021) Smart Approach for Cost-Effective Genotyping of Single Nucleotide Polymorphisms. Kuwait Journal of Science, 48(2):1-11.

Gharahveysi, S., Abbasi, H. A., Irani, M., Abdullahpour, R. \& Mirhabibi, S. (2012) Polymorphism investigation of calpastatin gene in Zel sheep population of Iran by PCR-RFLP method. African Journal of Biotechnology, 11(13):3211-3214.

Gorlov, I. F., Shirokova, N. V., Randelin, A. V., Voronkova, V. N., Mosolova, N. I., Zlobina, E. Y., Kolosov, Y. A., Bakoev, N. F., Leonova, M. A. \& Bakoev, S. Y. (2016) CAST/MspI gene polymorphism and its impact on growth traits of Soviet Merino and Salsk sheep breeds in the South European part of Russia. Turkish Journal of Veterinary and Animal Sciences, 40(4):399-405. 
Grobet, L., Martin, L. J. R., Poncelet, D., Pirottin, D., Brouwers, B., Riquet, J., Schoeberlein, A., Dunner, S., Ménissier, F. \& Massabanda, J. (1997) A deletion in the bovine myostatin gene causes the double-muscled phenotype in cattle. Nature genetics, 17(1):71-74.

Ibrahim, A., Ismail, I., Shehata, M. \& El-Beltagy, A. (2015) Calpastatin polymorphism in Barki lambs and their effects on growth and carcass traits. The Journal of American Science, 11(3):106-112.

Ibrahim, W. I. \& Kali, A. (2017) Effect of Polymorphism of Calpastatin gene, Age on meat Tenderness for Carcasses in Local Awassi sheep. Egyptian Journal of sheep and goats sciences, 12(2):1-10.

Ihsan, M., Dagong, A., Sumantri, C., Noor, R. R., Herman, R. \& Yamin, M. (2016) Polymorphisms of Calpastatin Gene and Its Association with Growth Traits in Indonesian Thin Tail Sheep. International Conference on Agricultural. Amsterdam, Netherlands.

Jamshidi, S., Karani, S. \& Goudarzi, M. (2014) Study polymorphism myostatin gene in Mehraban's sheep using PCR-RFLP method. Science International (Lahore), 26(3):1129-1135.

Jawasreh, I. \& Ismail, B. (2019b) Effects of calpastatin gene polymorphism on hematology and selected serum biochemical parameters in Awassi lambs. Journal of Advanced Veterinary and Animal Research, 6(2):193-196.

Jawasreh, K. I., Al-Amareen, A. H. \& Aad, P. Y. (2019a) Relationships between Hha1 Calpastatin Gene Polymorphism, Growth Performance, and Meat Characteristics of Awassi Sheep. Animals, 9(667):2-8.

Jawasreh, K. I., Jadallah, R., Al-Amareen, A., Abdullah, A. Y., Al-Qaisi, A., Alrawashdeh, I. M., Al-Zghoul, M., Ahamed, M. K. A. \& Obeidat, B. (2017) Association between MspI calpastatin gene polymorphisms, growth performance, and meat characteristics of Awassi sheep. Indian J. Anim. Sci, 87(5):635-639.

Jeanplong, F., Sharma, M., Somers, W. G., Bass, J. J. \& Kambadur, R. (2001) Genomic organization and neonatal expression of the bovine myostatin gene. Molecular and cellular biochemistry, 220(1-2):31-37.

Kambadur, R., Sharma, M., Smith, T. P. \& Bass, J. J. (1997) Mutations in myostatin (GDF8) in double-muscled Belgian Blue and Piedmontese cattle. Genome research, 7(9):910915.

Kaplan, S. \& Atalay, S. (2017) Determination of Calpastatin Gene Polymorphism in Kivircik Crossbred Ewes by PCR-RFLP Method. Selcuk Journal of Agriculture and Food Sciences, 31(3):147-150. 
Khan, S.-u.-H., Riaz, M. N., Ghaffar, A. \& Khan, M. F. U. (2012) Calpastatin (CAST) gene polymorphism and its association with average daily weight gain in Balkhi and Kajli sheep and Beetal goat breeds. Pakistan Journal of Zoology, 44(2):377-382.

Khederzadeh, S., Iranmanesh, M. \& Motamedi-Mojdehi, R. (2016) Genetic diversity of myostatin and calpastatin genes in Zandi sheep. Journal of Livestock Science and Technologies, $4(1): 45-52$.

Khederzadeh, S., Mobaraki, A., Haghi, H. A. \& Ezeddinloo, L. (2017) Analysis of the Third Exon of Myostatin Gene and the First Intron of Calpastatin Gene in Gray Shirazi Sheep Populations. International Journal of Agriculture Innovations and Research, 5(4):572-576.

Kulikova, K. A., Yuldashbaev, Y. A., Petrović, M. P., Caro-Petrović, V., Ružić-Muslić, D., Maksimović, N. \& Ostojić-Andrić, D. (2018) The polymorphism of cast gene in rams populations of the Tuvan breed. Genetika, 50(3):885-893.

Lazar, C., Gras, A. M., Rotar, M. C., Pistol, G. C., Pelmus, R. S. \& Ghita, E. (2016) Identification of Myostatin gene polymorphism using PCR-RFLP for improving carcass meat evaluation of Teleorman Black Head lambs. Scientific Papers Animal Science and Biotechnologies, 49(1):63-68.

Machado, A. L., Meira, A. N., Muniz, E. N., Azevedo, H. C., Coutinho, L. L., Mourão, G. B., Pedrosa, V. B. \& Pinto, L. F. B. (2020) Single loci and haplotypes in CAPN1 and CAST genes are associated with growth, biometrics, and in vivo carcass traits in Santa Inês sheep. Annals of Animal Science, 20(2):465-483.

Mahrous, K., Hassanane, M., Abdel, M. M., Shafey, H. \& Rushdi, H. (2015) Polymorphism of some genes associated with meat-related traits in Egyptian sheep breeds. Iranian Journal of Applied Animal Science, 5(3):655-663.

McPherron, A. C. \& Lee, S.-J. (1997) Double muscling in cattle due to mutations in the myostatin gene. Proceedings of the National Academy of Sciences, 94(23):12457-12461.

Mohammadi, M., Nasiri, M. B., Alami-Saeid, K., Fayazi, J., Mamoee, M. \& Sadr, A. (2008) Polymorphism of calpastatin gene in Arabic sheep using PCR-RFLP. African Journal of Biotechnology, 7(15):2682-2684.

Montes, V. D., Lenis, V. C. \& Hernández, H. D. (2019) Polymorphisms of the calpain and calpastatin genes in two populations of colombian creole sheep. Revista MVZ Córdoba, 24(1):7113-7118.

Mosher, D. S., Quignon, P., Bustamante, C. D., Sutter, N. B., Mellersh, C. S., Parker, H. G. \& Ostrander, E. A. (2007) A mutation in the myostatin gene increases muscle mass and enhances racing performance in heterozygote dogs. PLoS genetics, 3(5):e79. 
Nada, E., Mahrous, K. F. \& Salem, L. M. (2013) Genetic polymorphism detection in four genes in Egyptian and Saudi sheep breeds. World Applied Sciences Journal, 27(1):33-43.

Nanekarani, S. \& Goodarzi, M. (2014) Polymorphism of candidate genes for meat production in Lori sheep. IERI Procedia, 8:18-23.

Nanekarani, S., Khederzadeh, S. \& Kaftarkari, A. M. (2011) Genotypic frequency of calpastatin gene in Atabi sheep by PBR method. International Conference on Food Engineering and Biotechnology. IPCBEE.

Nassiry, M. R., Tahmoures, P. M., Javad, M. A., Soltani, M. \& Foroutani, F. S. (2006) Calpastatin polymorphism and its association with daily gain in Kurdi sheep. 4(3):188-192.

Nikmard, M., Molaee, V., Eskandarinasab, M. P., Dinparast Djadid, N. \& Vajhi, A. R. (2012) Calpastatin polymorphism in Afshari sheep and its possible correlation with growth and carcass traits. Journal of Applied Animal Research, 40(4):346-350.

O'Rourke, B. A. (2010) Genetic variation in the bovine myostatin gene and its effect on muscularity. Ph.D. thesis, University of Melbourne, Melbourne, Australia.

Othman, O. E., Balabel, E. A. \& Mahfouz, E. R. (2016) Genetic characterization of myostatin and callipyge genes in Egyptian small ruminant breeds. Biotechnology, 15(1-2):44-51.

Palmer, B., Roberts, N., Hickford, J. \& Bickerstaffe, R. (1998) Rapid communication: PCRRFLP for MspI and NcoI in the ovine calpastatin gene. J. Anim. Sci, 76(5):1499-1500.

Pomitun, I., Rossokha, V., Boyko, Y., Guzevatyi, O., Shpilka, M. \& Kulibaba, R. (2019) Analysis of calpastatin and callipyge genes polymorphism in Prydniprovska meat sheep. Agricultural Science and Practice, 6(2):58-65.

Ranjbari, M., Hashemi, A., Mardani, K. \& Darvishzadeh, R. (2012) Allelic polymorphism of Makoei sheep calpastatin gene identified by a polymerase chain reaction and single-strand conformation polymorphism. Journal of Agricultural Science and Technology, 14:533-538.

Sahu, A. R., Jeichitra, V., Rajendran, R. \& Raja, A. (2017) Polymorphism in exon 3 of myostatin (MSTN) gene and its association with growth traits in Indian sheep breeds. Small Ruminant Research, 149:81-84.

Schuelke, M., Wagner, K. R., Stolz, L. E., Hübner, C., Riebel, T., Kömen, W., Braun, T., Tobin, J. F. \& Lee, S.-J. (2004) Myostatin mutation associated with gross muscle hypertrophy in a child. New England Journal of Medicine, 350(26):2682-2688.

Shariatzadeh, M., Ghazi, A., Motlagh, M. K. \& Mahdiyeh, M. (2014) Evaluation of Myostatin Gene Polymorphism in Farahani Sheep by PCR-RFLP Method. Journal of Cell \&Tissue, 5(2):157-163. 
Smith, T. P., Lopez-Corrales, N. L., Kappes, S. M. \& Sonstegard, T. S. (1997) Myostatin maps to the interval containing the bovine mh locus. Mammalian Genome, 8(10):742-744.

Soufy, B., Mohammadabadi, M., Shojaeyan, K., Baghizadeh, A., Ferasaty, S., Askari, N. \& Dayani, O. (2009) Evaluation of Myostatin gene polymorphism in Sanjabi sheep by PCRRFLP method. Journal of Animal Science Research, 19(1):81-89.

Suleman, M., Khan, S. U., Riaz, M. N., Yousaf, M., Shah, A. \& Ishaq, R. (2012) Calpastatin (CAST) gene polymorphism in Kajli, Lohi and Thalli sheep breeds. African Journal of Biotechnology, 11(47):10655-10660.

Sutikno, S., Yamin, M. \& Sumantri, C. (2011) Association of polymorphisms calpastatin gene with the bodyweight of local sheep in Jonggol, Indonesia. Media Peternakan, 34(1):1-6.

Szkudlarek-Kowalczyk, M., Wiśniewska, E. \& Mroczkowski, S. (2011) Polymorphisms of calpastatin gene in sheep. Journal of Central European Agriculture, 12(3):425-432.

Yilmaz, O., Cemal, I., Karaca, O. \& Ata, N. (2014) Association of Calpastatin (CAST) gene polymorphism with weaning weight and ultrasonic measurements of loin eye muscle in Kıvırcık lambs. Kafkas Üniversitesi Veteriner Fakültesi Dergisi, 20(5):675-680.

Zare, J. \& Mirhosseini, S. Z. (2013) Study on polymorphism of myostatin in Iranian karakul sheep breed by PCR-RFLP marker. Modern Genetics Journal, 8(1):111-116.

Submitted: $\quad 07 / 11 / 2020$

Accepted: $\quad 07 / 03 / 2021$

Revisded: $\quad 09 / 04 / 2021$

DOI: $\quad 10.48129 /$ kjs. 10955 